\title{
META-ANALYSIS: EFFECT OF DIABETES ON MENINGITIS INFECTION IN ADULTS
}

\author{
Sulaiman Putra Nagaring, Bhisma Murti
}

Masters Program in Public Health, Universitas Sebelas Maret

\begin{abstract}
Background: Diabetes mellitus has been associated with increased infection rates. Diabetes has been stated as risk for bacterial meningitis, in particular listeria meningitis although few studies have been done. The purpose of this study was to examine effect of diabetes on meningitis infection in adults.

Subjects and Method: A systematic review and meta-analysis was conducted by PRISMA flow diagram. The articles were collected from Google Scholar, Pubmed, and Science Direct databases. Keywords used ("effect of diabetes mellitus on meningitis") OR ("meningitis") OR ("meningitis infection") OR ("diabetes melitus") OR ("Adults") AND ("logistic regression"). Eligibility criteria were defined using the PICO model as follows, (1) population: adults, (2) intervention: diabetes mellitus, (3) comparison: non diabetes mellitus, and (4) outcome: meningitis. The inclusion criteria were full text, case control study, reported adjusted odds ratio, and published from year 2000 to 2018. Articles that met the criteria were analyzed by Revman $5 \cdot 3$.

Results: Meta-analysis involved 6 primary studies from China, United States, Taiwan, and Korea. This study showed that diabetes mellitus increased the risk of meningitis in adults $(\mathrm{aOR}=6.97 ; 95 \% \mathrm{CI}=4.64$ to $10.47 ; \mathrm{p}<0.001)$.
\end{abstract}

Conclusion: Diabetes mellitus increase the risk of meningitis in adults.

Keywords: meningitis, diabetes mellitus, meta-analysis

\section{Correspondence:}

Sulaiman Putra Nagaring. Masters Program in Public Health, Universitas Sebelas Maret. Jl. Ir. Sutami 36A, Surakarta 57126, Central Java. Email: sulaimanputran@gmail.com. Mobile: 085855533027. 